\title{
Interaction of psychopathic traits in the prediction of cyberbullying behavior
}

\author{
María López-Larrañaga and Izaskun Orue \\ Universidad de Deusto, Bilbao, España
}

\begin{abstract}
The principal aim of the present study was to analyze whether the interaction of three psychopathic traits (callousunemotional, grandiose-manipulative and impulsive-irresponsible) longitudinally predicts the perpetration of cyberbullying behaviors in adolescents. The sample consisted of 741 participants (379 girls and 357 boys) aged 14 to $19(M=15.33 ; S D=1.14)$. Participants completed measures of the three traits at time 1 and measures of cyberbullying perpetration at time 1 and time 2 (one year apart). The results show that grandiose-manipulative and impulsive-irresponsible traits longitudinally predicted cyberbullying behaviors. Furthermore, callous-unemotional traits predicted cyberbullying when impulsivity levels were high. The interaction grandiosity $\times$ impulsivity was also significant, suggesting that each predicts cyberbullying behavior when the levels of the other variable are low. These findings have implications for both prevention and intervention and highlight the importance of taking into account these three psychopathic traits to better predict cyberbullying behavior among adolescents.
\end{abstract}

Keywords: Cyberbullying; callous-unemotional; grandiose-manipulative; impulsive-irresponsible; adolescents.

Resumen: Interacción de los rasgos psicopáticos en la predicción de la conducta de cyberbullying. El objetivo principal del presente estudio fue analizar la interacción de tres rasgos psicopáticos (dureza-emocional, grandiosidad-manipulativa e impulsividad-irresponsabilidad) en la predicción de conductas de cyberbullying. Participaron 741 adolescentes $(51.5 \%$ chicas; edad media $=15.33 ; D T=1.14)$. Se midieron los tres rasgos en el tiempo 1 y la perpetración de cyberbullying tanto en tiempo 1 como en el tiempo 2 (un año después). Los resultados mostraron que los rasgos de grandiosidad e impulsividad predecían longitudinalmente la aparición de conductas de ciberbullying. Además, el rasgo frialdad emocional predecía dichas conductas cuando los niveles de impulsividad eran altos. La interacción de los rasgos grandiosidad e impulsividad también resultó significativa, de lo que se deduce que la presencia elevada de uno de los rasgos es por sí misma predictora de conductas de cyberbullying. Estos resultados subrayan la importancia de atender estos tres rasgos psicopáticos para una mejor prevención de las conductas de ciberbullying entre adolescentes.

Palabras clave: Cyberbullying; dureza emocional; grandiosidad; impulsividad; psicopatía.

\section{Introduction}

Bullying is defined as repeated aggression, intended to cause harm, which happens in a context of power imbalance (Olweus, 1993). Four decades of research in this area have shown that this is a prevalent problem in schools throughout the world (Chester et al., 2015) and several antibullying programs have been developed (e.g.,

Recibido: 20 de febrero 2019: aceptado: 02 de abril 2019.

Correspondencia: Izaskun Orue, Universidad de Deusto, Avenida de las Universidades 24, 48007 Bilbao, España. Correo-e: izaskun.orue@, deusto.es
Garaigordobil, 2011). Simultaneously to this progress in research about bullying, new forms of harassment have appeared. Violent behaviors that were previously only perpetrated "face to face" are now also carried out through new technologies. This phenomenon is known as cyberbullying and is considered an extension of traditional bullying (Patchin, \& Hinduja, 2006). Specifically, cyberbullying was defined by Smith et al. (2008) as an aggressive and intentional behavior that is repeated frequently over time through the use, by an individual or a group, of electronic devices over a victim who cannot easily defend him/herself. This definition includes actions such as sending offensive, grotesque, 
or threatening text messages, spreading rumors online, and identity theft (Calvete, Orue, Estévez, Villardón, \& Padilla, 2010; Kowalski, Limber, \& Agatston, 2010; Ortega, Del Rey, \& Casas, 2016).

Research about the prevalence of cyberbullying is recent, but studies show a rapid growth. In a metaanalysis that included 80 studies on traditional bullying and cyberbullying, the authors found a mean prevalence rate of $15 \%$ for cyberbullying (Modecki, Minchin, Harbaugh, Guerra, \& Runions, 2014). Most studies indicate that boys carry out more cyberbullying compared to girls (Calmaestra et al., 2016; Calvete et al., 2010). The prevalence evidenced in the various studies has generated a growing interest in the consequences of cyberbullying. Several studies found physical and emotional problems in the victims (Avilés, 2013; Brown, Demaray, Tennant, \& Jenkins, 2017; Estévez, Villardón, Calvete, Padilla, \& Orue, 2010; Magaz, Chorot, Santed, Valiente, \& Sadín, 2016; Van Geel, Vedder, \& Tanilon, 2014), but aggressors present future problems such as criminal behavior, alcohol and drug abuse, and school absenteeism (Aviles, 2013; Garaigordobil, 2017; Hemphill, Kotevski, \& Heerde, 2015).

Given the high prevalence and the serious consequences of cyberbullying, it is important to identify the risk factors associated with these behaviors. In this study we have focused on studying the psychopathic traits associated with the perpetration of cyberbullying behaviors.

Traditionally, psychopathy has been studied only in adults (Leistico, Salekin, DeCoster, \& Rogers, 2008). However, in the past decade, numerous studies have shown their utility for children and adolescents (Salekin \& Lynam, 2010). In order to explore the dimensionality of psychopathy, some studies have relied on factor analysis (Andershed, Kerr, Stattin, \& Levander, 2002; Cooke \& Michie, 2001; Frick, Bodin, \& Barry, 2000; van Baardewijk et al., 2010) and have found that psychopathic personality among children and adolescents is characterized by three interrelated dimensions: affective, interpersonal, and behavioral.

Referring to the affective dimension (callousunemotional traits), these individuals are characterized by experiencing coldness or emotional hardness, that is, weak and superficial emotions; affective indifference; cruelty; lack of empathy, guilt, or remorse; and inability or great difficulty in establishing lasting connections with other people. This trait is related to the apparent presence of anhedonia (Essau, Sasagawa, \& Frick, 2006; Herpers, Rommelse, Bons, Buitelaar, \& Scheepers, 2012). Research has shown that these callousunemotional traits are related to proactive aggression in general (Orue, Calvete, \& Gámez-Guadix, 2016) as well as to bullying and cyberbullying (Ciucci, Baroncelli, Franchi, Golmaryami, \& Frick, 2014; Fanti, 2013; Orue \& Andershed, 2015). In fact, when the relationship between cyberbullying and each of the features of psychopathy has been studied independently, callousunemotional traits are the ones that have presented a closer relationship (Salekin \& Frick, 2005; Vinet, 2010). Besides, this relationship has also been demonstrated in longitudinal studies, such as the one conducted by Fanti, Demetriou, and Hawa (2012), which found that the trait of callousness was related to cyberbullying in a significant and longitudinal way.

On the interpersonal level (grandiose-manipulative dimension), the main symptoms are narcissistic, deceptive and artificial, arrogant, and self-centered attitudes as well as desires of dominance and manipulation. This feature of grandiosity is characterized by an exaggerated need for admiration, search for glory, and a tendency to be very aware of himself/herself; his/her successes, pleasures, appearance, and achievements; and the need to stand out visibly in front of others, be recognized, and receive admiration. People with these traits tend to presume that others envy them, and they present arrogant behaviors and attitudes. This feature of grandiosity has also been shown to be related to aggressive behaviors in adolescents (Orue et al., 2016) as well as to behaviors of bullying (Fanti, Demetriou, \& Hawa, 2012; Orue \& Andershed, 2015), which is consistent with the notion that bullying is characterized by the aggressor's desire to obtain high status and a powerful position inside the peer group (Salmivalli, 2010).

Third, the behavioral level of psychopathy (impulsiveirresponsible dimension) includes boredom, emotional instability, search for stimulation, lack of reflection before acting, and lack of capacity to establish longterm goals. Previous studies have found a relationship between impulsivity and bullying (Fanti \& Kimonis, 2012) and cyberbullying (Gámez-Guadix, Villa-George, \& Calvete, 2014; Low \& Espelage, 2014).

Recently, various authors have highlighted the importance of studying the three psychopathic traits and examining the interactions between them (Salekin, 2017). Up to now, few studies have studied the effect of the interaction of the three psychopathic traits. For example, Colins et al. (2014) found that the interaction of these traits serves to predict the occurrence of behavioral problems more effectively than when analyzing just one of them. Specifically, they found that the combination of high scores in the three dimensions, and the interaction between them, serves to predict with greater certainty the appearance of behavioral problems. More recently, 
Fanti, Kyranides, Lordos, Colins, and Andershed (2018) found that in predicting conduct disorder symptoms, the combination of high initial levels of conduct disorder symptoms and CU traits as well as the combination of conduct disorder symptoms, grandiosity, and impulsivity can lead to clinical levels of future conduct disorder symptoms. In reference to cyberbullying behavior, Orue and Andershed (2015) found in a cross-sectional study that the interaction between grandiosity and callousunemotional traits significantly predicted cyberbullying behaviors.

To sum up, the main objective of this study was to analyze the longitudinal effect of the interaction between the three psychopathic traits on the perpetration of cyberbullying behaviors among adolescents. Specifically, we expected to find that the three psychopathic traits of callous-unemotional, grandiosity, and impulsivity individually predict the perpetration of cyberbullying. Furthermore, we expected to find that the interactions between these traits will increase the predictive value of the three psychopathic traits model.

\section{Method}

\section{Participants}

The sample consisted of 741 participants, all of them high school students from 13 schools in Bizkaia (Spain). A group sampling procedure was employed using the schools as sampling units, stratified according to the type of school (public vs. private) and urbanity. Of the sample, 379 were girls (51.5\%) and 357 (48.5\%) boys (5 participants did not indicate their gender). Participants were between 13 and 17 years old $(M=15.33 ; S D=1.14)$. The majority was Spanish $(90.1 \%)$ but also South American (7.9\%). The remaining 2\% came from several countries. Socioeconomic levels were determined by applying criteria recommended by the Spanish Society of Epidemiology, Family, and Community Medicine (2000), which are based on information about parental occupation and income. Using these criteria, the sample's distribution was $12.9 \%$ low, $17.1 \%$ low-medium, $33 \%$ medium, 29.1\% high-medium, and 7.9\% high.

\section{Instruments}

We used the Youth Psychopathic Traits InventoryShort Form (YPI-S; van Baardewijk et al., 2010) to measure psychopathic traits. This is a self-report instrument that evaluates three psychopathic traits: the grandiose-manipulative or interpersonal dimension, the callous-unemotional or affective dimension, and the impulsive-irresponsible or behavioral dimension. The inventory consists of 18 items that are answered on a 4-point Likert scale ranging from 1 (totally disagree) to 4 (totally agree). Some of the items on the questionnaire are: "I think that crying is a sign of weakness even if nobody sees you" for the callous-unemotional traits, "I usually speak and then I think" for the trait of impulsivity, and "I find it easy to manipulate other people" for the trait of grandiosity. The instrument has good psychometric properties in its original form (Colins, Noom, \& Vanderplasschen, 2012) and also in its Spanish version (Orue \& Andershed, 2015). In this study, the instrument presented adequate reliability in all three dimensions. Specifically, Cronbach's alpha was .73 for callous-unemotional traits, .83 for grandiosity and .73 for impulsivity.

We used the Cyberbullying Questionnaire (CBQ; Calvete, Orue, Estévez, Villardón, and Padilla, 2010) which contains 14 items that show the frequency with which the adolescents have carried out different cyberbullying behaviors. It contains items such as "Record videos or take pictures of someone to upload or send" or "Post humiliating images of a peer on the Internet." It is answered according to a Likert-type scale, where the response options range from 0 (Never) to 3 ( 5 or more times) to evaluate the frequency with which the adolescent has performed what is described in each item. The psychometric properties of the Spanish version of the CBQ determine good construct validity and internal consistency (Calvete et al., 2010). In the present study, Cronbach's alpha coefficient was .76 both at Time 1 (T1) and Time 2 (T2).

\section{Procedure}

In order to preserve the anonymity of the participants, before the administration of the questionnaires the members of the educational centers gave the parents of the adolescents an informed consent form in which they could reject the participation of their son/daughter. The participants, who filled out the questionnaires in class, were informed that the answers were confidential and would only be read by the research team. Likewise, they were encouraged to ask in case of confusion regarding any item. Participation was voluntary, and students could leave the study at any moment if they wished. Data were collected on two measurement occasions spaced 1 year apart. To assure anonymity, a code was used to match the questionnaire in Time 1 (T1) with its corresponding in Time 2 (T2). The ethics committee of the University of [masked institution name] approved the study. 


\section{Data Analysis}

We used hierarchical regression models to evaluate the extent to which psychopathic traits longitudinally predict the perpetration of cyberbullying behaviors either individually or in conjunction. Firstly, T1 cyberbullying was introduced as a predictor and T2 cyberbullying was introduced as the criterion variable. Secondly, the three psychopathic traits were added as predictor variables. Following the procedure recommended by Frazier, Tix, and Barron (2004), the scores of the predictor variables were transformed into $\mathrm{Z}$ scores to reduce the problems of multicollinearity among the variables in the regression equation. Thirdly, the interactions between the variables introduced in step 2 were introduced (callous-unemotional traits $\times$ impulsivity, grandiosity $\times$ impulsivity, and callous-unemotional traits $\times$ grandiosity). The fourth and final step was to introduce the triple interaction term (callous-unemotional traits $\times$ grandiosity $\times$ impulsivity).

\section{Results}

Table 1 displays the descriptive statistics (mean and $S D$ ) and the Pearson correlations between all variables of the study. All the correlations were significant, with highest correlations between the variables of cyberbullying perpetration at $\mathrm{T} 1$ and $\mathrm{T} 2$, which means stability in the measure. Further, the psychopathic traits were related to each other and to the cyberbullying perpetration both at $\mathrm{T} 1$ and $\mathrm{T} 2$.

Table 2 displays the hierarchical regression analysis, where the traits of grandiosity and impulsivity longitudinally predicted cyberbullying behaviors. Callous-unemotional traits did not predict cyberbullying significantly. Moreover, a statistically significant interaction was found between the grandiosity and impulsivity traits and between callous-unemotional and impulsivity traits. As Figure 1 shows, the relation between impulsivity and cyberbullying changed depending on the

Table 1. Descriptive statistics and correlations among study variables

\begin{tabular}{lccccccc}
\hline \multicolumn{1}{c}{ Variables } & 1 & 2 & 3 & 4 & 5 & $M$ & $D T$ \\
\hline $1 . \mathrm{CB} \mathrm{T} 1$ & - & & & & & 1.69 & 2.58 \\
2. CB T2 & $.50^{* *}$ & - & & & 1.35 & 2.33 \\
3. CU & $.14^{* *}$ & $.25^{* *}$ & - & & 2.91 & 3.15 \\
$4 . \mathrm{GM}$ & $.36^{* *}$ & $.30^{* *}$ & $.37^{* *}$ & - & & 3.32 & 3.72 \\
$5 . \mathrm{II}$ & $.28^{* *}$ & $.26^{* *}$ & $.28^{* *}$ & $.38^{* *}$ & - & 6.04 & 3.63 \\
\hline
\end{tabular}

Note . CBT1 = Cyberbullying in time 1; CBT2 = Cyberbullying in time 2; CU = Callous-Unemotional; GM = Grandiose-Manipulative; II $=$ Impulsive-Irresponsible. ${ }^{*} p<.05, * * p<.01$

Table 2. Hierarchical multiple regression in which psychopathy dimensions predict cyberbullying perpetration

\begin{tabular}{lccccc}
\hline & $B$ & $E T$ & $\beta$ & $t$ & ${\text { Change in } \mathrm{R}^{2}}$ \\
\hline Step 1 & & & & & $\mathrm{R}^{2}=.25 ; \mathrm{F}(1,516)=172.9^{* *}$ \\
CB T1 & .42 & .09 & .44 & $10.97^{* *}$ & $\Delta \mathrm{R}^{2}=.04 ; \Delta \mathrm{F}(3,513)=8.72^{* *}$ \\
Step 2 & & & & & \\
GM & .30 & .12 & .13 & $2.61^{* *}$ & $\Delta \mathrm{R}^{2}=.01 ; \Delta \mathrm{F}(3,510)=3.32^{*}$ \\
II & .27 & .10 & .11 & $2.64^{* *}$ & \\
CU & .21 & .11 & .08 & 1.90 & \\
Step 3 & & & & & \\
GM $\times$ II & -.26 & .10 & -.11 & $-2.47^{*}$ & \\
CU $\times$ II & .22 & .11 & .09 & $1.99^{* *}$ & \\
CU $\times$ GM & .14 & .10 & .70 & 1.38 & \\
Step 4 & & & & & \\
CU $\times$ GM $\times$ II & -.16 & .98 & -.11 & $-2.08^{*}$ & \\
\hline
\end{tabular}

Note. $\mathrm{CB}=$ cyberbullying; $\mathrm{GM}=$ Grandiose-Manipulative; $\mathrm{II}=$ Impulsive-Irresponsible; $\mathrm{CU}=$ Callous-Unemotional traits. $* p<.05$, $* * p<.001$ 
level of grandiosity. In fact, cyberbullying was related to impulsivity when adolescents scored low on grandiosity traits $(B=0.525, t=3.623, p<.001)$; whereas when the levels of grandiosity were high there was no significant relation ( $B=0.015, t=0.104, p=.918)$. Similarly, grandiosity did not predict cyberbullying when the levels of impulsivity were high $(B=0.045, t=0.311, p=.756)$; but it did when impulsivity levels were low $(B=0.555$, $t=3.830, p<.001)$.

As mentioned above, the interaction between callousunemotional and impulsivity traits was also significant. Figure 2 displays this interaction. As can be seen, the relation between impulsivity and cyberbullying changed depending on the level of callous-unemotional traits. When adolescents scored low on the callousunemotional dimension, their scores on impulsivity did not correlate with cyberbullying behaviors $(B=0.048$, $t=0.331, p=.741$ ). However, when callous-unemotional traits were high, the relation between impulsivity and cyberbullying was significant $(B=0.492, t=3.395$, $p=.001)$. In the same way, the relation between callousunemotional traits and the perpetration of cyberbullying behaviors was only significant for those adolescents with high impulsivity scores $(B=0.422, t=2.912, p=.004)$ and not for those adolescents whose scores were low $(B=-0.022, t=-1.152, p=.879)$.

Finally, the interaction of the three psychopathic traits was also significant on the prediction of cyberbullying behaviors. We plotted the 3-way interaction (Figure 3) and tested the statistical significance of slope differences among the slopes using procedures suggested by Aiken and West (1991). The results indicated that impulsivity traits were only related to the perpetration of cyberbullying behaviors when grandiosity levels were low and callousunemotional traits were high (slope 3 in Figure $3 ; B=0.912$, $\mathrm{t}=4.079, p<.001$ ). Impulsivity traits were not related to cyberbullying when grandiosity and callous-unemotional traits were low (slope 4 in Figure 3; $B=0.146, t=0.792$, $p=.429)$, neither when scores on both traits where high (slope 1 in Figure $3 ; B=0.080, t=0.496, p=.62$ ), nor when levels of grandiosity were high and callous-unemotional traits low (slope 2 in figure $3 ; B=-0.042, t=-0.188$, $p=.851)$. The results indicate that the slope differences between (1) and (3), $t=-3.65, p<.001$, between (2) and (3) $t=-2.80, p=.005$, and between (3) and (4) $t=2.71$, $p=.007$ were statistically significant.

\section{Discussion}

The main purpose of this study was to shed light on a matter barely examined. Although there are many studies that have analyzed the relation between psychopathic

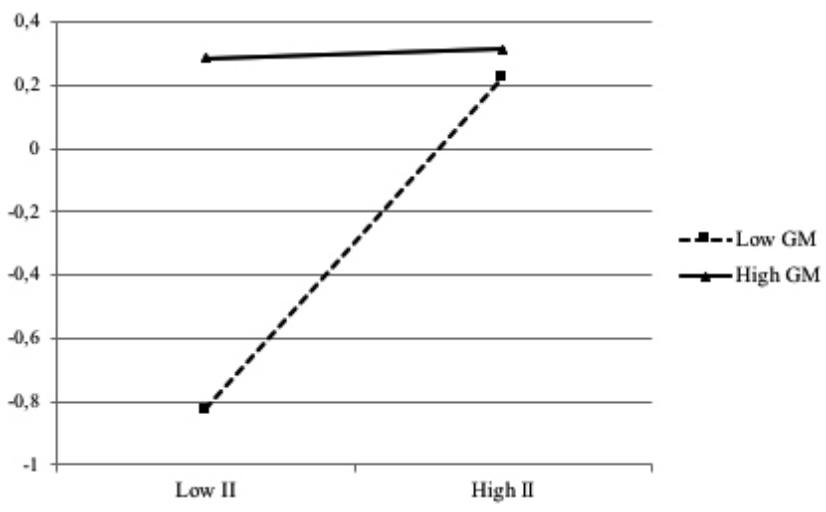

Figure 1. Interaction between grandiose-manipulative and impulsive-irresponsible traits in the prediction of cyberbullying behaviors. GM = Grandiose-Manipulative; II = ImpulsiveIrresponsible.

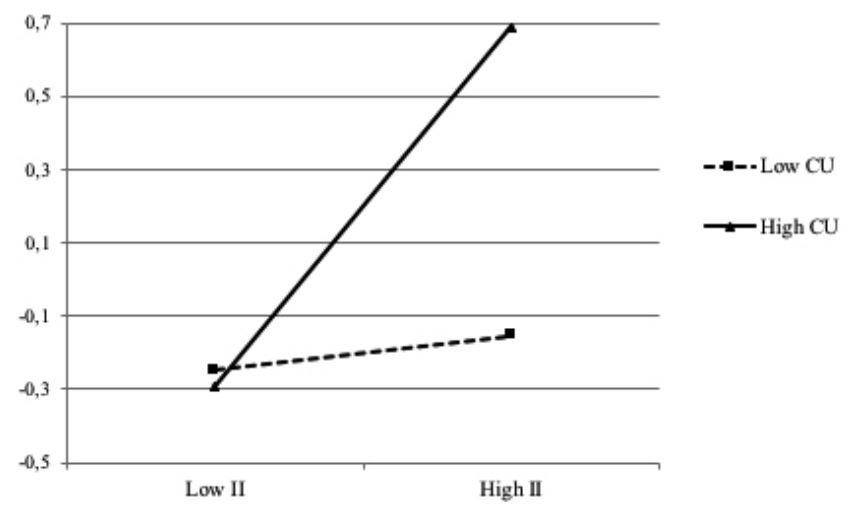

Figure 2. Interaction between callous-unemotional and impulsiveirresponsible traits in the prediction of cyberbullying behaviors. II = Impulsive-Irresponsible; CU = Callous-Unemotional traits.

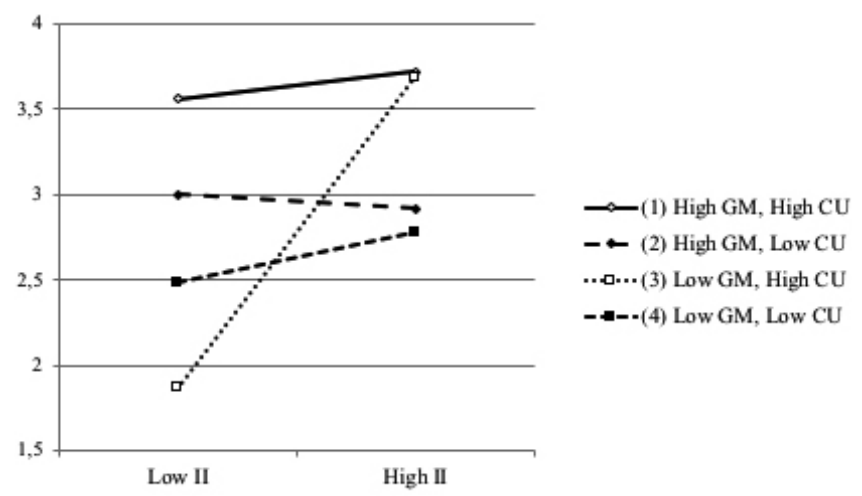

Figure 3. Three-way interaction of callous-unemotional, grandiose-manipulative, and impulsive-irresponsible traits in predicting cyberbullying behaviors. GM = GrandioseManipulative; II = Impulsive-Irresponsible; $\mathrm{CU}=$ CallousUnemotional traits

personality traits and cyberbullying behaviors, very few studies have focused on traits' interaction effects on these behaviors. Therefore, the main purpose of this study was 
to analyze the predictive role of three psychopathic traits (callous-unemotional, grandiose-manipulative, and impulsive-irresponsible) on cyberbullying perpetration.

Firstly, at a correlational level, the three psychopathic traits showed a significant relation with cyberbullying both at $\mathrm{T} 1$ and at $\mathrm{T} 2$. These results are similar to those found in other studies about bullying and cyberbullying (Fanti, Demetriou, \& Hawa, 2012; Orue \& Ansdershed, 2015; Orue \& Calvete, 2016; Reijntjes et al., 2016). Secondly, the results of regression analyses showed that the role of each trait was different. On the one hand, these analyses suggest that grandiosity and impulsivity traits predict cyberbullying behaviors individually, but without an additive effect. Therefore, in agreement with other studies, we find that grandiosity is in itself predictor of general aggression (Calvete, Orue, Gámez-Guadix, \& Bushman, 2015; Thomaes, Bushman, Stegge, \& Olthof, 2008) and also of cyberbullying (Ang, Tan, \& Talib, 2011; Antoniadou, Kokkinos, \& Markos, 2016; Carpenter, 2012; Orue \& Andershed, 2015). This result supports the idea that those adolescents who score high in grandiosity can employ aggression to achieve social status, to show who is on top or to gain admiration (Brummelman, Thomaes, \& Sedikides, 2016). It is important to note that narcissism peaks in adolescence and reduces later (Foster, Campbell, \& Twenge, 2003) and therefore it is important to study its consequences in this stage. It should be noted that there are some adolescents who score high in narcissism who are not able to adequately face new situations (Silva \& Mejía, 2015) and may suffer disappointments and frustration. These adolescents could find on the Internet a place where they have power and a value that in real life they do not possess. That is, they can find in cyberbullying behaviors a way to feel themselves capable, free, and unpunished.

On the other hand, the interaction between callousunemotional and impulsivity traits was statistically significant. These results, along with those found on the triple interaction, suggest that callous-unemotional traits predict cyberbullying behaviors only when the levels of impulsivity are high, but not when impulsivity is low. Similarly, impulsivity predicts cyberbullying only when the adolescent scores high in callous-unemotional traits. In this case, there occurs an enhancing interaction. That is, characteristics such as lack of empathy and emotional hardness are not enough to perpetrate cyberbullying; however, the combination of these characteristics, with a lack of reflection before acting and the need to seek stimulation, make the adolescent more likely to perpetrate cyberbullying. This result suggests that both traits are necessary to carry out cyberbullying behaviors, and that therefore it is essential to take into account both when studying the effects of psychopathy. These results are not consistent with the ones found by Orue and Andershed (2015) in their study about the interaction of psychopathic traits in predicting cyberbullying, but it should be noted that their study was cross-sectional, whereas the results of this study are longitudinal.

This study has some limitations that offer opportunities for future research. The principal limitation is that all questionnaires used in the present study were self-reports. Future studies should add other sources of information such as parents, peers, or teachers. Also, it would be helpful to add to the sample participants between 12 and 14 years old. As literature explains, the highest prevalence of cyberbullying behaviors occurs in this age range (Castro, 2016). Finally, the sample consisted of students from the community. It would be interesting to replicate this study in a forensic sample. However, we consider that the longitudinal design, the size of the sample, and the use of validated instruments are strengths of this study.

The results found in the present study add to the growing evidence that supports the importance of assessing all psychopathic traits to better predict behavioral problems (Fanti et al., 2018; Salekin, 2017). The results also have implications for the prevention of and intervention in cyberbullying in the school setting. They suggest that working with the three psychopathic traits is important. For prevention and intervention, it would be advisable to educate and raise awareness of cyberbullying and the importance of certain personality traits. Schools should add to their antibullying programs the promotion of empathy, the internalization of values (Frick, 2001), and activities to discourage grandiosity traits (Thomaes, Bushman, Orobio de Castro, Cohen, $\&$ Denissen, 2009). In addition, these programs should also include methods to control impulsiveness, such as problem-solving techniques (Conduct Problems Prevention Research Group, 2002). The prevention and intervention techniques should be applied through both individual and group dynamics, in which an atmosphere without acts of violence can be created.

\section{Conflicts of interest}

The authors have no conflicts of interest to declare.

\section{References}

Aiken, L. S., \& West, S.G. (1991). Multiple regression: Testing and interpreting interactions. Newbury Park: Sage.

Andershed, H., Kerr, M., Stattin, H., \& Levander, S. (2002). Psychopathic traits in non-referred youths: A new assessment 
tool. In E. Blaauw \& L. Sheridan (Eds.), Psychopaths: Current International Perspectives (pp. 131-158). The Hague: Elsevier.

Ang, R. P., Tan, K., \& Talib, M. A. (2011). Normative beliefs about aggression as a mediator of narcissistic exploitativeness and ciberbullying. Journal of Interpersonal Violence, 26, 2619-2634. doi: 10.1177/0886260510388268.

Antoniadou, N., Kokkinos, C., \& Markos, A. (2016). Possible common correlates between bullying and cyber-bullying among adolescents. Psicología Educativa, 22, 27-38. doi: 10.1016/j.pse.2016.01.003.

Avilés, J. M. (2013). Análisis psicosocial del ciberbullying: Claves para una educación moral. Papeles del Psicólogo, 34, 65-73.

Brown, C. F., Demaray, M. K., Tennant, J. E., \& Jenkins, L. N. (2017). Cyber Victimization in High School: Measurement, Overlap With Face-to-Face Victimization, and Associations With Social-Emotional Outcomes. School Psychology Review, 46, 288-303. doi:10.17105/SPR-2016-0004.V46-3

Brummelman, E., Thomaes, S., \& Sedikides, C. (2016). Separating narcissism from self-esteem. SAGE Journals, 25, 8-13. doi: 10.1177/0963721415619737.

Calmaestra, J., Escorial, A., García, P., Del Moral, C., Perazzo, C., \& Ubrich, T. (2016). Yo no juego a eso. Bullying y ciberbullying en la infancia. Madrid: Save the Children España.

Calvete, E., Orue, I., Estévez, A., Villardón, L., \& Padilla, P. (2010). Cyberbullying in adolescents: Modalities and aggressors' profile. Computers in Human Behavior, 26, 1128 1135. doi: 10.1016/j.chb.2010.03.017.

Calvete, E., Orue, I., Gámez-Guadix. M., \& Bushman, B. J. (2015). Predictors of Child-toParent Aggression: a 3-Year Longitudinal Study. Developmental Psychology, 51, 663- 676. doi:10.1037/a0039092

Carpenter, C. J. (2012). Narcissism on Facebook: Self-promotional and anti-social behavior. Personality and Individual Differences, 9, 54-59. doi:10.1016/j.paid.2011.11.011.

Castro, C. (2016). El fenómeno de la violencia entre iguales en España. Roles, género, edad, actitudes y estrategias de intervención. Cátedra Paralela, 13, 127- 154.

Chester, K. L., Callaghan, M., Cosma, A., Donnelly, P., Craig, W., Walsh, S., \& Molcho, M. (2015). Cross-national time trends in bullying victimization in 33 countries among children aged 11, 13 and 15 from 2002 to 2010. The European Journal of Public Health, 25(suppl_2), 61-64.doi:10.1093/eurpub/ ckv029.

Ciucci, E., Baroncelli, A., Franchi, M., Golmaryami, F. N., \& Frick, P. J. (2014). The association between callousunemotional traits and behavioral and academic adjustment in children: Further validation of the Inventory of CallousUnemotional Traits. Journal of Psychopathology and Behavioral Assessment, 36, 189-200. doi: 10.1007/s10862013-9384-z.

Colins, O. F., Andershed, H., Frogner, L., Lopez-Romero, L., Veen, V., \& Andershed, A. K. (2014). A New Measure to Assess Psychopathic Personality in Children: The Child Problematic Traits Inventory. Journal of Psychopathology and Behavioral Assessment, 36, 4-21. doi: 10.1007/s10862-0139385-y.

Colins, O. F., Noom, M., \& Vanderplasschen, W. (2012). Youth Psychopathic Traits Inventory-Short Version: A further test of the internal consistency and criterion validity. Journal of
Psychopathology and Behavioral Assessment, 34, 476-486. doi: 10.1007/s10862-012-9299-0

Cooke, D. J., \& Michie, C. (2001) Refining the construct of psychopathy: Towards a hierarchical model. Psychological Assessment, 13, 171-188. doi: 10.1037//1040-3590.13.2.171.

Conduct Problems Prevention Research Group (2002). The implementation of the Fast Track Program: An example of a large-scale prevention science efficacy trial. Journal of Abnormal Child Psychology, 30, 1-17. doi: 10.1023/A:1014292830216.

Essau, C., Sasagawa, S., \& Frick, P. (2006). Callous-unemotional traits in a community sample of adolescents. Assessment, 2(10), 1-17. doi:10.1177/10731106287354.

Estévez, A., Villardón, L., Calvete, E., Padilla, P., \& Orue, I. (2010). Adolescentes víctimas de cyberbullying: Prevalencia y características. Behavioral Psychology/Psicología Conductual, 18, 73-89.

Fanti, K., Demetriou, A., \& Hawa, V. (2012). A longitudinal study of ciberbullying: Examining risk and protective factors. Eruopean Journal of Developmental Psychology, 9, 168-181. doi: 10.1080./17405629.2011.643619.

Fanti, K. A., \& Kimonis, E. R. (2012). Bullying and victimization: The role of conduct problems and psychopathic traits. Journal of Research on Adolescence, 22, 617-631. doi:10.1111/j.1532-7795.2012.008909.x

Fanti, K. A., Kyranides, M. N., Lordos, A., Colins, O. F., \& Andershed, H. (2018). Unique and interactive associations of callous-unemotional traits, impulsivity and grandiosity with child and adolescent conduct disorder symptoms. Journal of Psychopathology and Behavioral Assessment, 40, 40-49. doi: 10.1007/s10862-018-9655-9

Foster, J. D., Campbell, W. K., \& Twenge, J. M. (2003). Individual differences in narcissism: Inflated self-views across the lifespan and around the world. Journal of Research in Personality, 37, 469-486. doi:10.1016/S0092-6566(03)000266

Frazier, P. A., Tix, A. P., \& Barron, K. E. (2004). Testing moderator and mediator effects in counseling psychology research. Journal of Counseling Psychology, 51, 115-134. doi: 10.1037/0022-0167.51.1.115.

Frick, P. J. (2001). A comprehensive and individualized treatment approach for children and adolescents with conduct disorders. Cognitive and Behavioral Practice, 7, 30-37. doi:10.1016/ S1077-7229(00)80005-X.

Frick, P.J., Bodin, S. D., \& Barry, C. T. (2000). Psychopathic traits and conduct problems in community and clinic-referred samples of children: further development of the psychopathy screening device. Psychological Assessment, 12, 382-393. doi: $10.1037 / 1040-3590.12 .4 .382$

Gámez-Guadix, M., Villa-George, F., \& Calvete, E. (2014). Psychometric properties of the Cyberbullying Questionnaire (CBQ) among Mexican adolescents. Violence and Victims, 29, 232-247. doi: 10.189/0886-6708.VV-D-12-00163R1.

Garaigordobil, M. (2011). Prevalencia y consecuencias del ciberbullying: Una revisión. International Journal of Psychology and Psychological Therapy, 11, 233-254. doi: 10.1080/13676261.2014.992324.

Garaigordobil, M. (2017). Psychometric properties of the Cyberbullying Test, a screening instrument to measure cybervictimi- 
zation, cyberaggression, and cyberobservation. Journal of Interpersonal Violence, 32, 3556-3576. doi: 10.1177/ 0886260515600165

Hemphill, S.A., Kotevski, A., \& Heerde, J. A. (2015). Longitudinal associations between cyber-bullying perpetration and victimization and problem behavior and mental health problems in young Australians. International Journal of Public Health, 60, 227-237. doi:10.1007/s00038-014-0644-9.

Herpers, P., Rommelse, N., Bons, D., Buitelaar, J., \& Scheepers, F. (2012). Callous-unemotional traits as a cross-disorders construct. Social Psychiatry and Psychiatric Epidemiology, 47, 2045-2064. doi: 10.1007/s00127-012-0513-x.

Kowalski, R., Liber, S., \& Agatston, P. (2010). Cyber Bullying: El acoso escolar en la era digital. Bilbao: Desclée de Browser

Leistico, A. M. R., Salekin, R. T., DeCoster, J., \& Rogers, R. (2008). A large-scale meta-analysis relating the hare measures of psychopathy to antisocial conduct. Law and Human Behavior, 32, 28-45. doi: 10.1007/s10979-007-9096-6.

Low, S., \& Espelage, D. (2014). Conduits from community violence exposure to peer aggression and victimization: Contributions of parental monitoring, impulsivity, and deviancy. Journal of Counseling Psychology, 61, 221-231. doi: 10.1037/a0035207.

Magaz, A. M., Chorot, P., Santed, M. A., Valiente, R. M., y Sandín, B. (2016). Evaluación del bullying como victimización: Estructura, fiabilidad y validez del Cuestionario de Acoso entre Iguales (CAI). Revista de Psicopatología y Psicología Clínica, 21, 77-95. doi: 10.5944/rppc.vol.21.num.2.2016. 16990.

Modecki, K., Minchin, J., Harbaugh, A. G., Guerra, N. G., \& Runions, K. C. (2014). Bullying prevalence across contexts: A meta-analyses measuring cyber and traditional bullying. Journal of Adolescent Health, 55, 602-611.doi: 10.1016/j. jadohealth.2014.06.007.

Olweus, D. (1993). Bullying at school: what we know and what we can do. Oxford: Wiley-Blackwell.

Ortega, R., Del Rey, R., \& Casas, J. A. (2016). Evaluar el bullying y el ciberbullying validación española del EBIP-Q y del ECIP-Q. Psicología Educativa, 22, 71-79. doi: 10.1016/j. pse.2016.01.004.

Orue, I., \& Andershed, H. (2015). The Youth Psychopathic Traits Inventory-Short Version in Spanish Adolescents-Factor Structure, Reliability, and Relation with Aggression, Bullying, and Cyber Bullying. Journal of Psychopathology and Behavioral Assessment, 37, 563-575. doi: 10.1007/s10862015-9489-7.

Orue, I., \& Calvete, E. (2016). Psychopathic traits and moral disengagement interact to predict bullying and cyberbullying among adolescents. Journal of Interpersonal Violence. doi: $10.1177 / 0886260516660302$.

Orue, I., Calvete, E., \& Gámez-Guadix, M. (2016). Gender moderates the association between psychopathic traits and aggressive behavior in adolescents. Personality and Individual Differences, 94, 266-271. doi:10.1016/j. paid.2016.01.043
Patchin, J., \& Hinduja, S. (2006). Bullies move beyond the schoolyard. A preliminary look at cyberbullying. Youth Violence and Juvenile Justice, 4, 148-169. doi: 10.1177/ 1541204006286288

Reijntjes, A., Vermande, M., Thomaes, S., Goossens, F., Olthof, T., Aleva, L., \& Van der Meulen, M. (2016). Narcissism, Bullying, and Social Dominance in Youth: A Longitudinal Study. Journal of Abnormal Child Psychology, 44, 63-64. doi: 10.1007/s10802-015-9974-1.

Salmivalli, C. (2017). Bullying and the peer group: A review. Aggression and Violent Behavior, 15, 112-120. doi:10.1016/j. avb.2009.08.007

Salekin, R. T. (2017). Research Review: What do we know about psychopathic traits in children?. Journal of Child Psychology and Psychiatry, 58, 1180-1200. doi: 10.1111/jcpp.12738

Salekin, R. T., \& Frick, P. (2005). Psychopathy in Children and Adolescentes: The need for a Developmental Perspective. Journal of Abnormal Child Psychology, 33(4), 403-409. doi:10.1007/s10802-005-5722-2

Salekin, R. T., \& Lynam, D. R. (2010). Child and adolescent psychopathy: An introduction. In R. Salekin \& D. R. Lynam (Eds.), Handbook of Child and Adolescent Psychopathy (pp.111). New York, US: Guildford Press.

Silva, I., y Mejía, O. (2015). Autoestima, adolescencia y pedagogía. Revista Electrónica Educare, 19, 241-256. doi: 10.15359/ree.19-1.13.

Smith, P., Mabdavi, J., Carvalbo, M., Fisher, S., Russell, S., \& Tippet, N. (2008). Cyberbullying and its nature an impact in secondary school pupils. Journal of Child Psychology and Psychiatry, 49,376-385.doi:10.1111/j.1469-7610.2007.01846.x

Thomaes, S., Bushman, B. J., Orobio de Castro, B., Cohen, G. L., \& Denissen, J. J. (2009). Reducing narcissistic aggression by buttressing self-esteem: An experimental field study. Psychological Science, 20, 1536-1542. doi:10.1111/j.14679280.2009.02478.x

Thomaes, S., Bushman, B. J., Stegge, H., \& Olthof, T. (2008). Trumping shame by blasts of noise: Narcissism, self-esteem, shame, and aggression in young adolescents. Child Development, 79, 1792-1801. http:// dx.doi.org/10.1111/j. 1467-8624.2008.01226.x

Van Baardewijk, Y., Andershed, H., Stegge, H., Nilsson, K. W., Scholte, E., \& Vermeiren, R. (2010). Development and tests of short versions of the youth psychopathic traits inventory and the youth psychopathic traits inventory-child version. European Journal of Psychological Assessment, 26, 122-128. doi: 10.1027/1015-5759/a000017.

Van Geel, M., Vedder, P., \& Tanilon, J. (2014). Relationship between peer victimization, cyberbullying, and suicide in children and adolescents: a meta-analysis. JAMA Pediatrics, 168, 435-442. doi: 10.1001/jamapediatrics.2013.4143.

Vinet, E. (2010). Psicopatía infanto-juvenil: Avances en conceptualización, evaluación e intervención. Terapia Psicológica, 28, 109-118. doi: 10.4067/S0718-48082010000 100010. 